\title{
PREDAJNI KRAJOLIK VELEBITSKOG PODGORJA
}

\author{
Matija Dronjić \\ Etnografski muzej \\ Trg Mažuranića 14 \\ HR 10000 Zagreb \\ matija@emz.hr
}

UDK: 930.85(497.5 Velebit):398

Prethodno priopćenje

Ur.: 2017-03-03

Autor donosi sintezu višegodišnjih terenskih istraživanja Podgorja na temu predaja o tzv. "starom narodu", zakopanom blagu, fantastičnim bićima te događajima na granici stvarnosti i nemogućeg. Na temelju činjenice kako su mnogi zabilježeni sadržaji duboko usađeni u pripovjedačke tradicije lokalnog stanovništva i odnose se na točno određene lokacije, autor pokušava ocrtati konture predajnog krajolika prostora između Velebita i mora.

Ključne riječi: Podgorje, Velebit, usmene predaje, zakopano blago, fantastična bića

\section{Uvod}

Moj prvi susret s velebitskim Podgorjem zbio se u 2007. godine kada sam se kao student treće godine etnologije i kulturne antropologije Filozofskog fakulteta Sveučilišta u Zagrebu priključio timu istraživača na projektu Identitet i etnogeneza primorskih Bunjevaca pod vodstvom dr. sc. Milane Černelić. Naš cilj bio je istražiti lokalitete smještene uz trasu Jadranske magistrale od Senja do Karlobaga te naselja uz planinske ceste koje se odvajaju u smjeru Oltara, Alana i Baških Oštarija. S obzirom kako se radilo o doista velikom području čija je glavna značajka bio realno malen broj stanovnika i relativno velika udaljenost između naselja, istraživanja su se nastavila i iduće dvije godine, ali u okviru projekta Identitet $i$ etnokulturno oblikovanje Bunjevaca. ${ }^{1} \mathrm{Za}$ vrijeme mog boravka na terenu uspio sam prikupiti značajan korpus građe, mahom zapisa o vjerovanjima lokalnog stanovništva koje sam djelomično obradio i objavio u Senjskom zborniku u nekoliko navrata. ${ }^{2}$ Iako se nakon Podgorja istraživački

${ }^{1}$ Također pod vodstvom dr. sc. Milane Černelić. Više u M. ČERNELIĆ, 2013.

${ }^{2}$ M. DRONJIĆ, 2008; 2009. 
fokus projekta pomaknuo na područje južne Like, a zatim i zadarskog zaobalja, uspio sam još nekoliko puta u 2010. godini posjetiti Podgorje zahvaljujući potpori dr. sc. Milane Černelić i dobroti fra Stjepana Bergovca, tadašnjeg gvardijana Kapucinskog samostana u Karlobagu, čiji sam bio redoviti gost.

Već sljedeće godine, kao netom diplomiranom etnologu pružila mi se prilika raditi na manjem projektu u suradnji s Javnom ustanovom Park prirode Velebit u timu s dr. sc. Marijetom Rajković Iveta, čija je zadaća bila istražiti etnografsku baštinu srednjeg Velebita za potrebu izrade istoimene studije. ${ }^{3}$ Suradnja s Parkom prirode nastavljena je i 2012. godine, a nova su istraživanja rezultirala interdisciplinarnom studijom Povijesni putovi na području Parka prirode Velebit u koautorstvu s dr. sc. Borisom Olujićem i Krešimirom Čorkom. ${ }^{4}$ Krajem iste godine zaposlio sam se $u$ Etnografskom muzeju u Zagrebu te su moje podgorske "ekspedicije" ustupile mjesto drugim izazovima i zadatcima. Nakon pauze od nekoliko godina na primorske obronke srednjeg Velebita vratio sam se 2016. godine zahvaljujući pozivu dr. sc. Maria Katića s Odjela za etnologiju i kulturnu antropologiju Sveučilišta u Zadru, s kojim sam u sklopu projekta Mirila zaobalnog dijela primorske Hrvatske uspješno izveo još jedno terensko istraživanje. ${ }^{5}$

Svih ovih godina bilježio sam fragmente društvenog sjećanja, predaje i vjerovanja, sadržaje koje su moji kazivači nerijetko nazivali babljim pričama. Od prvih istraživačkih koraka fascinirao me odnos lokalnog stanovništva spram krajolika u kojem žive, a upravo su mi bablje priče koje bi se doticale određenih točaka u tom nepreglednom prostoru postale fokusom znanstvenog interesa.

O temi predajnog krajolika imao sam prilike govoriti na znanstvenostručnom skupu Podgorje: Polazište i perspektive razvoja. ${ }^{6} \mathrm{~S}$ obzirom na temu skupa, u samome referatu odlučio sam se više fokusirati na problematiku razvoja područja koje se bori s nestankom stanovništva, čemu sam i sam svjedočio proteklih deset godina, a u što sam se s kolegom Mariom Katićem itekako uvjerio tijekom posljednjeg istraživanja. ${ }^{7}$ Ovaj se rad donekle sadržajno

${ }^{3}$ M. RAJKOVIĆ IVETA - M. DRONJIĆ, 2011.

${ }^{4}$ B. OLUJIĆ - K. ČORAK - M. DRONJIĆ, 2012.

${ }^{5}$ Nažalost, u dosadašnjem radu nisam bio u mogućnosti posvetiti se istraživanjima prostora južnog Podgorja pa ću se za potrebe ovog izlaganja fokusirati na podatke koje je objavila Mirjana Trošelj u tekstu Mitske predaje i legende južnovelebitskog Podgorja (2011).

${ }^{6}$ Skup je održan 13. i 14. listopada 2016. godine u Senju, u organizaciji Instituta društvenih znanosti Ivo Pilar - područni centar u Gospiću, Gradskog muzeja Senj te Društva Senjana i prijatelja Senja u Zagrebu.

7 Ponukani rezultatima istraživanja, kolega Mario Katić i ja odlučili smo zajednički progovoriti o problematici terenskog istraživanja na područjima gdje se događa proces rapidne depopulacije u radu metodološkog predznaka koji je u pripremi. 
odmiče od referata sa spomenutog skupa, odnosno u njemu se želim fokusirati na prikaz sinteze rezultata mojih dosadašnjih terenskih istraživanja radi pokušaja ocrtavanja kontura predajnog krajolika Podgorja.

\section{Uvod u predajni krajolik}

Način na koji lokalno stanovništvo kroz predaje - jednostavne pripovjedačke oblike - percipira prostor nametnuo se kao vrlo interesantna tema već u ranim fazama istraživanja Podgorja. Klasično određenje predaje kao folklornog oblika (ili usmenoknjiževne vrste) počiva na činjenicama kako se radi o kratkoj, najčešće jednoepizodnoj proznoj formi, čiji se sadržaj percipira od "publike" kao nedvojbeno istinit ma koliko god bio nevjerojatan, iracionalan ili fantastičan. ${ }^{8}$ Uz standardne figure kojima se razrađuje kontekst, poput utvrđivanja izvora same priče, vremena radnje te neposredne identifikacije protagonista, ${ }^{9}$ prostorna ubikacija sadržaja ističe se kao vrlo bitan element.

Karakteristike podgorskogkrajolika ostavile su snažan tragu pripovjedačkom repertoaru njegovih žitelja. Promatrajući prikupljene tekstove razvidno je kako je život lokalnog stanovništva u predindustrijskim vremenima (pa sve do sedamdesetih ili osamdesetih godina 20. stoljeća) bio neraskidivo povezan s Velebitom. Njihova radnja odvija se na planini i strmim stazama, dok je more uglavnom u drugom planu. ${ }^{10}$ Izuzev kazivanja etiološkog predznaka različitih motiva, prevladavaju tri motivska kompleksa koji se međusobno isprepliću, brišući granice između klasične žanrovske podjele predaja - sadržaji o tzv. "starom stanovništvu", tj. fantastičnim žiteljima ovih prostora u davnini, o zakopanom blagu te o različitim nadnaravnim bićima i događajima na granici zbilje i nemogućeg.

Pričanja Podgoraca su na prvi pogled jedinstvena, ali gotovo svi elementi motivskih kompleksa imaju svoje odgovarajuće analogije u istovjetnim folklornim oblicima populacija naseljenih na širem području, odnosno dijelom su arhaičnih pripovjedačkih tradicija velike rasprostranjenosti. ${ }^{11}$ Iako su predaje nerijetko lišene povijesnosti, a u njima se stvarnost isprepliće s fantastičnim motivima, nikako ih ne treba odbaciti kao besmislice jer dočaravaju način na koji su Podgorci tumačili svijet oko sebe pripisujući značenja određenim točkama vlastita zavičaja. ${ }^{12}$

\footnotetext{
${ }^{8}$ Usp. M. BOŠKOVIĆ-STULLI, 2006, 22.

${ }^{9}$ Protagonisti su redovito stvarni ljudi, primjerice: To mi je jedan, neki Nikola Budak kaživa u Karlobagu. Iz Ledenika je rodom (M. DRONJIĆ, 2009, 252).

${ }^{10}$ M. DRONJIĆ, 2014, 254.

${ }^{11}$ M. DRONJIĆ, 2008, 253; V. PALAVESTRA, 2004, 14.

${ }^{12}$ M. RAJKOVIĆ IVETA - M. DRONJIĆ, 2011, 58.
} 


\section{Obrisi predajnog krajolika velebitskog Podgorja}

Onomastika je grana lingvistike koja proučava značenje i nastanak vlastitih imena, poput raznih toponima, tj. vlastitih imena naselja ili nekog geografskog objekta kao što su planine, doline, rijeke itd. Na istraživanom području evidentno je postojanje velikog broja raznovrsnih toponima čije je značenje naoko skriveno, ali se u predajama lokalnog stanovništva sačuvalo sjećanje na okolnosti njihova nastanka. Iz njih je moguće iščitati lokalna prezimena uz informacije o geografskom položaju same lokacije (primjerice Vrbanska Duliba, Matešić Pod itd.) ili namjenu određenog prostora (Sinokos, Mlinište i sl.). ${ }^{13}$ Međutim, pojedini sadržaji otkrivaju se tek u razgovoru s lokalnim stanovništvom u čijem društvenom sjećanju žive brojne predaje etiološkog i historijskog predznaka. ${ }^{14}$

Mnoštvo sadržaja povezuje se s tragičnim događajima. Primjerice, kazivači su navodili kako je Dušikrava dobila ime po nečijoj kravi koja se ugušila u obližnjem bunaru, ${ }^{15}$ a Svatska draga nazvana je jer su tamo išli svatovi i toliko je nevrijeme udarilo da su svi izginili. ${ }^{16}$ Nagla promjena vremena na planini i podno nje vrlo je stvarna i za život opasna pojava, pa ne čudi kako velik broj toponima u sebi krije sjećanje na nesretne događaje uzrokovane iznenadnim nevremenom. Primjerice, Mirjana Trošelj bilježi kako je Bojinac ili Bojin kuk nazvan po djevojci koju je na planini ubio grom dok je čuvala blago. ${ }^{17}$

U kontekstu tragičnih događaja često se pojavljuje i motiv sukoba, pa tako druga inačica predaje o Svatskoj dragi naglašava kako se radi o mjestu na kojem se dogodila tučnjava s fatalnim posljedicama između dvije svadbene povorke koje su se upravo tu susrele. ${ }^{18}$ Najčešći protagonisti u scenarijima koji uključuju sukobe su Turci, a priče su ubicirane u vrijeme osmanlijskih pustošenja Podgorja. Ovisno o predaji, Turska su vrata dobila ime po pljačkaškim pohodima ili pogibiji turske vojske, baš kao i Lomivrat, gdje su ih naši starosjedioci natjerali da poskaču dolje u samo more $!^{19}$ Razbojište je također dobilo ime po turskom razbojanju, što je kazivač dodatno pojasnio postojanjem obližnjeg Hodžinog brda koje je dobilo ime prema lokaciji pogibije spomenutoga. I ime planinskog naselja Tuževac koje se smjestilo nedaleko od Razbojišta svjedoči o turbulentnim

\footnotetext{
${ }^{13}$ M. IVANUŠ - R. LISAC - D. ŠUŠNJIĆ, 2011, 6.

${ }^{14}$ Usp. M. BOŠKOVIĆ-STULLI, 2006, 22.

${ }^{15}$ M. DRONJIĆ, 2009, 250.

${ }^{16}$ Milan Balen, Franić, r. 1931. godine, Balenska Draga.

${ }^{17}$ M. TROŠELJ, 2011, 363.

${ }^{18}$ Vladimir (Vladan) Balen, Jurić, r. 1922. godine, Živi Bunari.

${ }^{19}$ M. DRONJIĆ, 2009, 250.

${ }^{20}$ Niko Vrban, r. 1957. godine, Matešić Pod.
} 
vremenima, jer prema predaji ti razbojnici nisu mogli ništa napraviti jer su ih tu dočekali malo bolji dečki. U Tuževac kad su došli, tužni su ošli. ${ }^{20}$

Razvidno je kako mnoštvo naziva evocira asocijacije na slične sadržaje, ali neki su s vremenom promijenili svoja "originalna" imena na što su pojedini kazivači revno upozoravali: Ispod Kubusa di je onaj tunel, ima kuća jedna. Cestarska. I mi ono područje zovemo Mamidovac. Ali ne! To se zove Muhamedovac, jer je tu turski paša Muhamed poginija. ${ }^{21}$

$\mathrm{S}$ druge strane, neki se naoko očigledni primjeri tumače drukčije. Tako se iza toponima Sadikovac krije priča koja u potpunosti odudara od očekivanog tradicijskog obrasca: Taj je lugar stari umro, Dane Mažuran. Sadika! Stari je Dane... A pazi, stari su ga zvali Sadika! Sad pazi da ti ispričam! Ima Bosanac travar, Sadika Sadiković. On se bavio ljekovitim biljem. A Sadika je taj, Dane, ima dvajstri godine, dvajsčetri, kad je obolio od tuberkuloze. I on dođe u Riku, u Sušak zapravo. On dođe u hošpital, u bolnicu. Tamo je bija neki doktor $i$ on njemu kaže, on je vidija da je to tuberkuloza, nije onda bilo penicilina, nema mu spasa. On njemu kaže: "Neće vam bit ništa, vi ste mladi, odite kući i uživajte što vam je god moguće. Jedite, pijte!" I on jadan, što će, kući. I on se dočepa knjige Sadike Sadikovića. I zato se od Konjskog jedno brdo tamo zove Sadikovac. Vidite vi, to je živa istina, a to nije bilo davno. To je bilo jedno prije sedamdeset godina. Brdo nazvali po njemu, a po toj knjigi. Jer je Dane iša brat trave, kadulju u cvitu, u tu stranu jednu koja se poslije nazvala Sadikovac. I on je kuva mlijeko domaće, med i kadulju tu. Pravija sirup. I on je to pija. I on dođe za godinu dana u hošpital kod toga doktora isto. Ovo je živa istina! I doktor kaže: "No Mažuran, jeste vi živ il' mrtav?" Ovaj se začudija pa kaže: "Doktore, živ sam!"22

Promjene u pripovjedačkim obrascima odvijaju se u skladu s duhom vremena i uporno redefiniraju predajni krajolik u većoj ili manjoj mjeri. Jedan od uzroka je svakako viša razina formalnog obrazovanja sugovornika koja je spontano ugrađena u tradicijski tekst. Drugim riječima, reinterpretacije temeljene na novim saznanjima o prošlosti ovih prostora bile su nužne kako se utemeljenost elemenata predajnog krajolika na činjenicama koje proizlaze iz društvenog sjećanja ne bi dovela u pitanje, čime se ni dalje ne sumnja u istinitost sadržaja.

Modifikacije elementa tradicijskog teksta pod utjecajem više razine obrazovanja najvidljivije su u motivskom kompleksu predaja o starom stanovništvu. Materijalne ostatke života "starog naroda", odnosno ljudi koji su prema predaji nastanjivali ove krajeve u nekom prošlom vremenu ${ }^{23}$ današnji

\footnotetext{
${ }^{21}$ M. DRONJIĆ, 2009, 250.

${ }^{22}$ Božo Kovačević, Čokin, r. 1940. godine, Vidovac Cesarički.

${ }^{23}$ Najčešće nedefiniranom, za razliku od ranije spomenutih "turskih" motiva.
} 
stanovnici prepoznaju po oronulim zidinama i bunarima kojima ne pamte vrijeme nastanka. Pri označavanju starog stanovništva najrasprostranjeniji termin je Grk, ali se ponegdje javljaju i Rimljani, Iliri i Turci ${ }^{24}$, dok su na prostoru južnog Podgorja trag ostavili i Mlećani. ${ }^{25}$

Na području sjeverne i središnje morske padine Velebita zabilježio sam nemali broj predaja o grčkim bunarima, a uz pomoć lokalnog stanovništva uspio sam barem pobliže odrediti lokaciju njih oko dvadesetak ${ }^{26}$. Ljudi ih razlikuju od "mlađih" bunara prema izgledu (kružnog su oblika, nerijetko s kamenim obzidom i popločenjima) i vrlo kvalitetnom načinu gradnje, a iznimku predstavlja osam bunara kvadratnog oblika, građenih od materijala koji podsjeća na stučenu ciglu i izgleda kao kad se šaluje zid ${ }^{27}$ u okolici Vidovca Cesaričkog. Potonji opis neodoljivo podsjeća na rimski Opus cementicium ${ }^{28}$ ili neku srodnu tehniku gradnje, a s obzirom na to da je spomenuto područje naseljeno od prapovijesnih vremena ${ }^{29}$ razvidno je kako je predaja o bunarima par excellance primjer tradicijske interpretacije arheoloških ostataka. U tom kontekstu grčki bunari nisu usamljeni, već se brojni potencijalni arheološki lokaliteti nazivaju grčkim zidinama, gradinama i sl. Primjerice, govorilo se kako su Grci živjeli na glavici nedaleko od Ažić Lokve (tristo duša je gore živilo) ${ }^{30}$, da su izgradili gradinu u Starigradu ${ }^{31}$, suhozide u Kupovini, Putiću i Starom toru u okolici Gustih zidina ${ }^{32}$, vinograde kod Jotluše ${ }^{33}$, crkvu i groblje na gradini sv. Trojice u Tribanj-Šibuljini ${ }^{34}$ itd.

${ }^{24}$ Supstitucija Grka navedenim terminima najbolje ilustrira kako pripovjedač modificira priču u skladu sa suvremenim spoznajama o povijesti vlastita zavičaja koji su mu dostupni putem školskog obrazovanja, literature ili medija (usp. DRONJIĆ, 2009, 264).

${ }^{25}$ M. TROŠELJ, 2011, 350, 36.

${ }^{26}$ Primjerice, dva bunara u neposrednoj blizini Matešić Poda, dva na putu od Matešić Poda prema Volaricama, dva na Orijama, dva pod vrhom Šuljba, dva nedaleko od Skorupova dolca, dva na Guvninama kod Cesarice (zvali su ih "blizanci"); po jedan kod Zidnica uz Šipovac, kod Bilaja, u Dragičević dolcu, na Bijeloj Selini (kod trafostanice); bunar zvan Tvrdovac nedaleko od Markovića, Osrdak nedaleko od Lopaca, Stružnjak kod Selina, Sušak kod Trnovca, Kajić i Čičavac kod Ažić Lokve (zatrpani), Ostrovica i Spomina na Plantaži iznad Trnovca (na putu za Ječmište) itd.

${ }^{27}$ Ivan Prpić, Grgin, r. 1967. godine, Vidovac Cesarički.

${ }^{28}$ M. SUIĆ, 1976, 108-110.

${ }^{29}$ Usp. V. GLAVAŠ, 2014, 12; M. GLAVIČIĆ, 2001, 207-209.

${ }^{30}$ Ivan Ažić, r. 1934. godine, Ažić Lokva.

${ }^{31}$ Tomo Modrić, Lovrić, r. 1931. godine, Gornja Klada.

${ }^{32}$ Tomo Matijević, Mrakanov, r. 1940. godine, Guste Zidine.

${ }^{33}$ Ivan Prpić, Grgin, r. 1967. godine, Vidovac Cesarički.

${ }^{34}$ M. TROŠELJ, 2011, 364-365. 
Pripadnike "starog naroda" zadesila je tragična sudbina. Većina predaja govori o njihovom egzodusu uzrokovanom fantastičnim događajima poput velikog snijega koji je pao usred ljeta ili vjetra koji je puhao bez prestanka godinama. ${ }^{35}$ Njihovo bogatstvo ilustriraju bezbrojne predodžbe o zakopanom blagu, a nastale su na temelju velikog broja različitih pripovjedačkih tradicija i čine kompleksan sklop, u kojemu se naziru fragmenti magijskih postupaka i vjerovanja, mutnih sjećanja na stvarne događaje, ali i realnu životnu neimaštinu te uz nju usko povezanu želju za bogaćenjem. ${ }^{36}$ Primjerice, u Vidovcu Cesaričkom pričalo se kako je blago "starog naroda" zakopano u misterioznom devetom bunaru koji nitko nije mogao pronaći, a čuva ga zmija - začarana djevojka. ${ }^{37} \mathrm{U}$ grčkim bunarima u Guvninama nedaleko od Cesarice, tzv. "blizancima", navodno su se mnogi utopili tražeći zlatne pjate ${ }^{38}$, a u sjevernom Podgorju priča se kako su se Grci vratili brodom i raspitivali se o Lukovu, nakon čega su odnijeli blago koje se nalazilo sakriveno u stijeni u koju udaraju valovi nedaleko od naselja, dvajst metari od mora. ${ }^{39}$

Protagonisti predaja ovog motivskog kompleksa katkad su i vladari "starog naroda", odnosno razni dehistorizirani i mitologizirani likovi ${ }^{40}$ poput, primjerice, cara Pasoglava, kraljice Jelene, Crne Kraljice i Marije Terezije koji se u raznim sižeima spominju uz ruševine starigradske Večke kule ${ }^{41}$, ili cara Trojana koji je sakrio veliko blago na Borovom vrhu (sjeverni Velebit). ${ }^{42}$ I kralj Bela IV. povezuje se uz zakopane dragocjenosti koje se prema jednoj verziji priče nalaze u Zovinama, a prema drugoj negdje između Jablanca i Turskih vrata, odnosno negdje oko Zlatnog bunarića, pojilišta koji su ljudi iskopali u potrazi za zlatom. ${ }^{43}$

Neizmjerno bogatstvo zakopano je uglavnom u raznim pećinama ili sličnim objektima, a moguće ih je identificirati na nekoliko načina. Kako bi se ušlo u pećinu s blagom ispod Razvoja, potrebno je čekati jutarnje sunce da razotkrije ulaz zatvoren žrvnjem, a pričalo se da je neki Modrić pronašao zlato

${ }^{35}$ M. DRONJIĆ, 2012, 145-149.

${ }^{36}$ LJ. MARKS, 1987, 61; M. DRONJIĆ, 2008, 242; 2012, 147.

${ }^{37}$ M. DRONJIĆ, 2008, 246; 2009: 252-253. Sličan motiv Mirjana Trošelj donosi za TribanjŠibuljinu (M. TROŠELJ, 2011, 364-365), a Nikola Bonifačić Rožin za kulinu kod Crnike, dalje Žrnovnice (N. BONIFAČIĆ ROŽIN, 1956, 62).

${ }^{38}$ Lucija Dokozić, r. 1935. godine, Pejakuša.

${ }^{39}$ M. DRONJIĆ, 2008, 244.

${ }^{40}$ Usp. M. DRONJIĆ, 2012, 147.

${ }^{41} \mathrm{M}$. TROŠELJ, 2011, 359-360.

${ }^{42}$ Ivan Ažić, r. 1934. godine, Ažić Lokva.

${ }^{43}$ M. DRONJIĆ, 2008, 250. 
koje su hajduci sakrili u pećini ispod Čepuraša, jednog od tri vrha istoimenog brda, zahvaljujući tome što ga je neki Vojvođanin savjetovao da potraži ulaz tako da gleda iznad kojeg vrha sunce izlazi prve nedjelje u osmom mjesecu. ${ }^{44}$ Slična predaja zabilježena je i u Živim Bunarima, a radi se o blagu u pećini ispod vrha Mandelovac čiji je ulaz gledao prema istoku (na mjesto gdje se pojavljuje jutarnje sunce). ${ }^{45}$ Uspješna potraga katkad ne ovisi o promatranju izlaska sunca, već je važno ugledati more koje se s pravog mjesta vidi na osobit način, primjerice, $u$ slučaju ulaza u pećinu nedaleko od Karlobaga ili prethodno spomenutog blaga Bele IV. u Zovinama. ${ }^{46}$

Lokacija zakopanog blaga, odnosno pećine u kojoj se nalazi, zapisana je u starim knjigama ${ }^{47}$ ili na nju upućuje kakav poseban znak. Primjerice, smještaj dragocjenosti u pećini na brdu Obljak može se prepoznati po uklesanom znaku ruke na stijeni. ${ }^{48}$ Također, domaće životinje mogu biti velika pomoć u potrazi, o čemu svjedoči predaja kako se u Velikoj dragi nedaleko od Gustih Zidina nalazi pećina u kojoj je blago na onom mjestu gdje koza zapne rogom kad uđe ${ }^{49}$. Kao čest motiv ovakvih predaja javlja se i predodžba kako je zlato pokriveno kamenom pločom, primjerice, u pećini u Asanovcu ${ }^{50}$, a u Jablancu se pričalo o nekom Jozi koji je sanjao da će ga pronaći ispod kamene ploče u svom vrtu. ${ }^{51}$

Planinski vrhovi i druga teško dostupna mjesta također su lokacije na kojima se prema predajama čovjek može obogatiti. Među njima svakako dominira Strogir, vertikalna monolitna stijena iznad Jablanca na koju se, prema pričanju lokalnog stanovništva, nitko nikad nije popeo: ...postoji nekakvo zlato, gori navrh Strogira i da se niko ne može popet, ko što se i niko nije popea na taj Strogir. Kaže, ako se neko popne, nać će gore zlato. ${ }^{52} \mathrm{O}$ posebnom značaju ovog planinskog kuka u pripovjedačkim tradicijama svjedoče brojne predaje u kojima se spominje kao lokacija na kojoj vile ili viške igraju kolo. ${ }^{53}$

Vile se bez iznimke opisuju kao lijepe i mlade djevojke fantastičnih osobina poput magarećih ili kozjih nogu, pomažu ljudima, ali im mogu i nauditi.

${ }^{44}$ M. DRONJIĆ, 2008, 247-248.

${ }^{45}$ M. DRONJIĆ, 2008, 248.

${ }^{46} \mathrm{U}$ oba slučaja, s točne pozicije more se vidi poput jedra broda (M. DRONJÍ, 2008, 249-250).

47 Takve predaje najčešće tematiziraju povratak "starog naroda" po blago (Usp. V. PALAVESTRA, 1966, 75-76, K 6.3; D. HIRC, 1996, 110; M. DRONJIĆ, 2008, 249).

${ }^{48}$ M. TROŠELJ, 2011, 361.

${ }^{49}$ M. DRONJIĆ, 2008, 251.

${ }^{50} \mathrm{M}$. TROŠELJ, 2011, 361.

${ }^{51}$ M. DRONJIĆ, 2008, 251.

${ }^{52}$ M. DRONJIĆ, 2009, 255.

${ }^{53}$ M. DRONJIĆ, 2009, 255. 
Uz pojam vile stanovnici Podgorja, ali i nekih rubnih područja, često vezuju atribut nagorkinja ili asocijaciju Vila Velebita ${ }^{54}$, što već samo po sebi govori dovoljno o prostoru njihovog predajnog habitata. Smatralo se kako žive u pećinama duboko u planini, a ljudi su ih viđali kako igraju kolo na usamljenim vrhovima poput Vilinog Kuka ili Velinca. ${ }^{55}$ Predaje o vilama vežu se i uz vodu, odnosno planinska pojilišta (jezera), izvore i bunare. S Vilinog Kuka bi silazile u Duboko na vodu, a jezero ispod Vaganskog i Babinog kuka nikad ne bi presušilo te je u njemu voda uvijek bila čista upravo zahvaljujući vilama. ${ }^{56}$

Uz Strogir se vežu i predaje o viškama, vješticama, a posebno je zanimljivo kako je to jedina podgorska lokacija vještičjih okupljanja koju sam uspio zabilježiti. ${ }^{57} \mathrm{Za}$ razliku od vila, koje se smatraju fantastičnim, onostranim bićima, vještice su bez iznimke ljudska bića, žene čiji je identitet poznat, ali ga se javno ne spominje iz straha od njihovih natprirodnih moći. Većina sadržaja vezanih uz viške, a i njima u jednu ruku komplementarne more, locirano je uz naselja u kojima su te osobe živjele, dok se u krajoliku pojavljuje široka lepeza fantastičnih bića poput vukodlaka, crnog čovjeka i raznih drugih noćnih utvara.

Upravo se u tim predajama, čije je vrijeme radnje noć, ocrtava koncept liminalnosti prostora, u kojem se na specifičnim mjestima brišu granice između dva svijeta. Fantastičnim događajima ljudi su uglavnom svjedočili na planinskim stazama i nepristupačnim lokacijama u krajoliku, na mjestima gdje je ružno proć po danu, a kamoli po noći. ${ }^{58} \mathrm{I}$ doista, u tekstovima predaja razvidno je vjerovanje kako opasnost naglo nestane s prvim zrakama sunca ${ }^{59}$, ili kada protagonist prijeđe simboličku granicu - kad začuje lavež pasa, tj. kad se približi selu. ${ }^{60}$

Kao prostor, u kojem se posebno opasno zateći u noći, ističe se zaleđe Cesarice. Na planinskim stazama između Pejakuše i Koromačine, na predjelu

${ }^{54}$ Usp. P. KELEMEN, 2009, 279-281; N. ŠKRBIĆ, 2000, 219.

${ }_{55}$ M. TROŠELJ, 2011, 361-362, M. DRONJIĆ, 2009, 255, N. BONIFAČIĆ ROŽIN, 1956, 70. Predaje o vilama i planinskim predjelima rasprostranjene su ne samo po Velebitu, Istri $i$ južnim Dinaridima, nego i drugim krajevima naše zemlje. (...) Adekvatan mitski prostor njihovo je stanište, primjerice kuk Vilin, izvor Bobika, Bobički kuk, Duboki jaz (jezero), Babino (Vilinsko) jezero, Vilinska vrata, Dušice i Vilenski kuk. (...) Kazivač Dane Rončević kaže da vile prolaze kroz Vilinska vrata kada idu na zborovanje, na Dušicama se sastaju, a na Vilenskom kuku plešu (M. TROŠELJ, 2011, 351).

${ }^{56}$ M. TROŠELJ, 2011, 362.

${ }^{57}$ M. DRONJIĆ, 2008, 251-252. Uglavnom prevladava predodžba kako se vještičji sastanci održavaju na Kleku.

${ }^{58}$ M. DRONJIĆ, 2009, 269.

${ }^{59}$ M. DRONJIĆ, 2009, 260.

${ }^{60}$ M. DRONJIĆ, 2009, 261. 
koji se naziva Rujine, viđao se Crni čovjek, misteriozno gorostasno biće koje bi prepriječilo put namjerniku. ${ }^{61} \mathrm{Na}$ istom putu ljudima bi se ukazivao i crni vol, a sličnu je priču u južnom Podgorju zabilježila Trošelj o crnom juncu iz Asanovačke pećine, možebitnom vukodlaku ili ukletoj duši koja je progonila nekog čovjeka sve do kuće ${ }^{62}$.

Planinski predio zvan Panos, između Lukova i Trnovca, također je poznata lokacija noćnih okršaja s crnim čovjekom i crnim jarcem..$^{63}$ Na Kosici (Dabarskoj kosi) čula se harmonika kako svira usred noći, a u Crnoj Dulibi ljudi su čuli pjesmu koja dolazi od neke jame i onda je počela i zora, i onda su vidjeli dvi zmije di skočiše sa drveta u jamu. Onda je više nestalo pisme i svega ${ }^{64}$ Konačno, uz planinske staze nalaze se mirila ili počivala, mjesta na kojima bi se zastajalo s pokojnikom kada bi ga se nosilo s planine na groblje te koja su obilježavana na poseban, lokalnim tradicijama uvjetovan način. ${ }^{65}$ I ona su smatrana lokacijama koje je dobro izbjegavati noću, a nerijetko se pričalo kako se na njima viđaju svjetla ${ }^{66}$ ili razne utvare. ${ }^{67}$

\section{Umjesto zaključka}

Predaja i krajolik nerazdvojni su elementi jedinstvene cjeline. Međutim, ne treba smetnuti s uma kako je glavna sastavnica predajnog krajolika čovjek, pripovjedač koji publici prenosi tradicijska znanja u koja neizostavno unosi djelić sebe, vlastitih iskustava, vrijednosti i stavova. Nažalost, na prostoru velebitskog Podgorja sve je teže susreti sugovornika koji ima lokalno znanje. Mnogih mojih kazivača danas više nema, a pojedina sela su sablasno prazna i gotovo neprepoznatljiva. Doduše, u južnom Podgorju demografska situacija čini se nešto boljom, poglavito zahvaljujući nešto boljoj razvijenosti turističkog sektora i relativnoj blizini Zadra, odnosno većeg centra. ${ }^{68}$ Umjesto zaključka, osvrnuo bih se ukratko na mogućnosti idealne ${ }^{69}$ primjene rezultata istraživanja

${ }^{61}$ M. DRONJIĆ, 2009, 259.

${ }^{62} \mathrm{M}$. TROŠELJ, 2011, 362-3.

${ }^{63}$ N. BONIFAČIĆ ROŽIN, 1956, 64-5

${ }^{64}$ M. DRONJIĆ, 2009, 261

${ }^{65}$ Više o mirilima u M. KATIĆ, 2010, 15-21; 2012.

${ }^{66}$ Primjerice, na mirilu kod Staništa u srednjem Podgorju: U Staništu kad nose dođu do Stina. Tu upočinu. Počinu na putu, a čunj dignu veše puta. (...) To stoji kao uspomena, da je tu počivao zadnji put. Plaše se tuda proći. Krste se. Kazivaju stari ljudi, da onuda svitli i kad je tišina, da se samo drveće njiše (N. BONIFAČIĆ ROŽIN, 1956, 1956: 17).

${ }^{67}$ Lucija Dokozić (r. 1935. godine, Pejakuša) kazivala je kako se na mirilu iznad sela pojavljivala utvara djevojčice koja je plakala.

${ }^{68}$ Procjena temeljena na diskusijama sa skupa Podgorje: Polazište i perspektive razvoja.

${ }^{69}$ Primjena nije problematizirana u kontekstu s demografske slike Podgorja. 
teme. Interes za produbljivanje znanja o tradicijskoj kulturi, tj. kulturnoj baštini žitelja morske padine Velebita od institucionalnih dionika u procesima kreiranja razvojnih i kulturnih politika svakako postoji, o čemu u najmanju ruku svjedoče dvije uspješne istraživačke kampanje u suradnji s Javnom ustanovom Park Prirode Velebit. Cilj tih kampanja bio je identificirati relevantne elemente baštine na temelju kojih bi se razvijali novi turistički proizvodi u okviru već postojećih kapaciteta i u suradnji s kreativnim industrijama. Kao ciljana skupina istaknuti su planinari i izletnici, tj. ljubitelji aktivnog turizma koji se ne ograničavaju samo na sadržaje vezane isključivo uz more ili isključivo uz planinu, već su spremni iskusiti poveznicu ta dva svijeta. S obzirom na to da velik dio predaja lokalno stanovništvo ubicira upravo u točke komunikacije između primorskih naselja i Velebita, smatram kako je obris predajnog krajolika svakako relevantan rezultat u kontekstu postavljenog cilja i definirane ciljane skupine. Konačno, ne treba smetnuti s uma kako su predaje vrlo atraktivan materijal za turističku prezentaciju jer ih nije potrebno posebno prilagođavati korisnicima zahvaljujući njihovoj kratkoj formi, neposrednosti i dinamici, dok ih njihov misteriozan prizvuk čini zanimljivima i najzahtjevnijoj publici. ${ }^{70}$

\section{Literatura i izvori}

Nikola BONIFAČIIĆ ROŽIN, Folklorna građa iz Hrv. Primorja, pod Velebitom, rkp. IEF 277, Zagreb, 1956.

Maja BOŠKOVIĆ-STULLI, Priče i pričanje, Zagreb, 2006.

Milana ČERNELIĆ, Osvrt na desetljetno sustavno etnološko istraživanje primorskoličkih Bunjevaca, Senjski zbornik, 40, 2013, 685-696.

Matija DRONJIĆ, Zakopano blago u usmenoj predaji Podgoraca, Senjski zbornik, 35, Senj, 2008, 241-256.

Matija DRONJIĆ, Usmene predaje velebitskog podgorja, Senjski zbornik, 36, Senj, 2009, 245-274.

Matija DRONJIĆ, Prilog istraživanju predaja o "starom narodu" na području Like i Podgorja, Senjski zbornik, 39, 2012, 133-154.

Matija DRONJIĆ, Bunjevci između planine i mora, Bunjevci u prostornom i vremenskom kontekstu, Zagreb, 2014, 245-258.

Dragutin HIRC, Hrvatsko Primorje, Rijeka, 1996.

Vedrana GLAVAŠ, Analize vidljivosti u prapovijesnom krajoliku Velebita, Archaeologia Adriatica, 7, Zadar, 2014, 1-26.

Miroslav GLAVIČIĆ, Fortifikacije na primorskom obronku Velebita između Senja i Karlobaga, Histria Antiqua, 7, Pula, 2001, 201-215.

\footnotetext{
${ }^{70}$ Usp. M. RAJKOVIĆ IVETA - M. DRONJIĆ, 2011, 57.
} 
Martina IVANUŠ - Rene LISAC - Dalibor ŠUŠNJIĆ, Kulturna baština Srednjeg Velebita (elaborat), Gospić, 2011.

Mario KATIĆ, Mirila: porijeklo i značenje, Mirila: kulturni fenomen, Ljubljana, 2010, 15-35.

Mario KATIĆ, Prilog istraživanju običaja obilježavanja mjesta odmaranja s pokojnikom, Studia mythologica Slavica, 15, Ljubljana, 2012, 117-134.

Petra KELEMEN, Vjerovanja u nadnaravna bića, Živjeti na Krivom Putu, sv. II, Zagreb, 2009, 279-292.

Ljiljana MARKS, Usmene predaje o zakopanom blagu, Etnološka tribina, 10, Zagreb, 1987, 61-66.

Boris OLUJIĆ - Krešimir ČORAK - Matija DRONJIĆ, Povijesni putevi na području Parka prirode Velebit (elaborat), Zagreb, 2012.

Vlajko PALAVESTRA, Narodna predanja o starom stanovništvu u dinarskim krajevima, $\operatorname{GlZM}(E)$, 20/21, Sarajevo, 1966, 5-86.

Vlajko PALAVESTRA, Historijska usmena predanja iz Bosne i Hercegovine. SarajevoZemun, 2004.

Marijeta RAJKOVIĆ IVETA - Matija DRONJIĆ, Etnografska baština srednjeg Velebita (elaborat), Zagreb, 2011.

Mate SUIĆ, Antički grad na istočnoj obali Jadrana, Zagreb, 1976.

Nevena ŠKRBIĆ, Pojedini elementi duhovne kulture primorskih Bunjevaca, Senjski zbornik, 27, Senj, 2000, 217-226.

Mirjana TROŠELJ, Mitske predaje i legende južnovelebitskog Podgorja, Studia mythologica Slavica, 14, Ljubljana, 2011, 345-370.

\section{THE TRADITIONAL LANDSCAPE OF VELEBIT PODGORJE}

Summary

The author gives a synthesis of many years of field investigations of Podgorje on the theme of the traditions of the so-called "old people", of buried treasure, fantastic creatures and events on the boundaries of reality and the impossible. Based on the fact of how many recorded subjects are deeply rooted in the narrative tradition of the local population and which relate to precisely defined locations, the author tries to outline the contours of the traditional landscape of the area between Velebit and the sea.

Keywords: Podgorje, Velebit, oral traditions, buried treasure, fantastic creatures 